\title{
Irrigation water quality may improve in arid regions of China
}

\author{
Guofeng Zhu ${ }^{1}$, Huiying Ma ${ }^{1}$, Yu Zhang ${ }^{1}$, Liyuan Sang ${ }^{1}$, Qiaozhuo Wan ${ }^{1}$, Zhiyuan Zhang ${ }^{1}$, \\ and Yuanxiao $\mathrm{Xu}^{1}$ \\ ${ }^{1}$ Northwest Normal University
}

December 12, 2020

\begin{abstract}
The stability and safety of water environment are the foundation of agricultural development. The possibility of salinization and desertification in the oasis agricultural area is much higher than that in other areas, for the population density, lack of water resources and high salinity. Therefore, it is necessary to study the water environment of irrigation water in this area, so as to make a reasonable water resource utilization and protection plan. In the agricultural irrigation period (from Apr. to Sep.) and non-irrigation period (from Oct. to Mar. of the next year), there were 9 sampling points set up from the source area to the oasis of the middle and lower reaches in Shiyang River Basin. Evaluating the irrigation water quality of surface water by ion concentration, SAR and end-member mixing diagram. The results shown: (1) the dilution effect of precipitation has a decisive influence on the ion concentration of surface water in the watershed. Due to the overlapping of irrigation period and rainy season, rainfall dilution makes irrigation water quality better. (2) There are spatial differences in hydrochemical types. The upstream hydrochemical type is mainly Ca-HCO3 type. The hydrochemical type of the middle and lower reaches is $\mathrm{Ca}(\mathrm{Na})$ - HCO3 mixed type. The upstream surface water is very suitable for agricultural irrigation, and the middle and downstream oasis area is suitable. (3) Surface rock weathering and evaporation crystallization are the main factors affecting the hydrochemical characteristics of surface water. Due to changes in the underlying surface environment in a short time, it is unlikely that the water quality will deteriorate. (4) In recent years, with the increase in precipitation caused by climate change and the strict environmental protection policies, the risk of deterioration of irrigation water quality is greatly reduced, surface water may be more suitable for agricultural irrigation.
\end{abstract}

\section{Hosted file}

manuscript.pdf available at https://authorea.com/users/370759/articles/498429-irrigationwater-quality-may-improve-in-arid-regions-of-china

\section{Hosted file}

Figure.pdf available at https://authorea.com/users/370759/articles/498429-irrigation-waterquality-may-improve-in-arid-regions-of-china

\section{Hosted file}

Table.pdf available at https://authorea.com/users/370759/articles/498429-irrigation-waterquality-may-improve-in-arid-regions-of-china 